\title{
DEVELOPMENT OF A NOVEL MICROBIOLOGICAL METHOD FOR DETECTION OF GAMMA IRRADIATED SPICES
}

\author{
Irina Mladenoska ${ }^{1}$, Nora Limani Bektashi*2, Beti Andonovic ${ }^{1}$, Hristina Spasevska ${ }^{3}$, Ivana Sandeva ${ }^{3}$, \\ Milica Arizanova ${ }^{3}$, Slobodan Masic ${ }^{4}$, Arianit A. Reka ${ }^{5}$ \\ ${ }^{1}$ Faculty of Technology and Metallurgy, Ss. Cyril and Methodius University, Skopje, North Macedonia \\ ${ }^{2}$ Faculty for Technological Sciences, Mother Teresa University, Skopje, North Macedonia \\ ${ }^{3}$ Faculty of Electrical Engineering and Informational Technology, Ss. Cyril and Methodius University, \\ Skopje, North Macedonia \\ ${ }^{4}$ Vinca Institute of Nuclear Sciences, Belgrade, Serbia \\ ${ }^{5}$ Department of Chemistry, Faculty of Natural Sciences and Mathematics, University of Tetovo, \\ Tetovo, North Macedonia \\ nora.limani@unt.edu.mk
}

\begin{abstract}
Spices are food additives that are used in many different areas of food technology. Most of the spices contain essential oils sensitive to thermal degradation processes. Therefore, an alternate method of decontamination, other than thermal, should be used so that the microbial safety of the spices is ensured. This study was focused on the evaluation of the effect of ionizing radiation, known as radurization, on microbiological safety in samples of red pepper, black pepper, and stinging nettle, from North Macedonia. Samples were irradiated by ${ }^{60} \mathrm{Co} \gamma$-rays. The possibility for development of a novel, shortened microbiological method was investigated. The conventional agar plate method was used, as a standard microbiological method, in order to evaluate the effect of irradiation on the microbiological safety of the food. The red pepper and the stinging nettle did not show any microbial growth when inoculated on both growth media, after being irradiated. Additionally, the photostimulated luminescence and thermoluminescence method were used as physical methods. By comparing the two glow curves for the glow ratio, the obtained values are greater than 0.1 , which confirms that the samples have been irradiated.
\end{abstract}

Keywords: microorganisms; decontamination; irradiation; food; spices; thermoluminescence; photostimulated luminescence

\section{РАЗВОЈ НА НОВ МИКРОБИОЛОШКИ МЕТОД ЗА ДЕТЕКЦИЈА НА ЗАЧИНИ ОЗРАЧЕНИ СО ГАМА ИРАДИАЦИЈА}

Зачините се адитиви за храна што се користат во многу различни области на прехранбената технологија. Повеќето зачини содржат етерични масла чувствителни на процеси на термичка деградација. Затоа треба да се користи алтернативен нетермички метод за деконтаминација, за да се обезбеди микробна безбедност на зачините. Ова истражување е фокусирано на евалуација на влијанието на јонизирачкото зрачење, познато како радуризација, врз микробиолошката безбедност на примероците од црвен пипер, црн пипер и коприва од Северна Македонија. Примероците се озрачени со ${ }^{60} \mathrm{Co} \gamma$-зраци. Истражена е можноста за развој на нов, скратен микробиолошки метод. Конвенционалниот метод (метод на агаризирани подлоги) се користеше како стандарден микробиолошки метод, со цел да се оцени ефектот на зрачење врз микробиолошката безбедност на храната. Црвениот пипер и копривата не покажаа микробен раст, кога беа инокулирани на двата медиуми за раст, откако беа озрачени. Дополнително, методите на фотостимулирана луминисценција и термолуминисценција се користеа како физички методи. Добиените резултати, сооднос на сјајност (на кривите за сјајност) поголем од 0,1, потврдуваат дека примероците се озрачени. 
Клучни зборови: микроорганизми; деконтаминација; зрачење; храна; зачини; Термолуминисценција; фотостимулирана луминисценција

\section{INTRODUCTION}

Food irradiation is a clean technology for non-thermal preservation of different kinds of food products. It is considered a "clean" technology, because after the processing no chemical residue is present in the food product. As a relatively new food safety technology, it enables elimination of both vegetative cells and spores of the spoilage, and pathogenic microorganisms. It guaranties a long product shelf life and microbial safety, thereby enabling less food loss [1]. Thus, it is a very environmentally friendly technology, compatible with the circular economy and the sustainable global development. According to the report of the EU project for reduction of food waste, around 88 million tonnes of food are wasted annually in the EU, with associated costs estimated at 143 billion euros [2]. Gamma irradiation is a technique that is most frequently used for radurization (cold pasteurization) and sterilization of food $[3,4]$. Low, medium and high doses of gamma irradiation are used for different purposes during the food treatment processes. Thus, low doses (up to $1 \mathrm{kGy}$ ) are used for inhibition of sprouting, insect disinfestations, and parasite disinfection. Medium doses (1-5 $\mathrm{kGy}$ ) are used for extension of shelf life, elimination of spoilage, and pathogenic microorganisms, while high doses (10 kGy) are used for industrial sterilization and decontamination of certain food additives [5]. In the reported review article [5], it has been concluded that the effectiveness of food irradiation, as a conservation process, is based mainly on the effective disruption of DNA molecules in the nuclei of cells, rendering them inactive.

An especially broad application of the irradiation processing might be expected when an additional treatment is needed for the minimally processed fruits and vegetables. Thus, Araújo et al. [6] used gamma irradiation to enable microbiological safety of minimally processed vegetables.

The actual dose employed is a balance between that which is needed and that which can be tolerated by the product, without objectionable changes (e.g. off-flavors, texture changes, flavor alterations). The most common irradiated commercial products are spices, fruits, and vegetables. Some of the frequently reported irradiated fruits are dates [7, 8], chestnuts [9], mushrooms [4], and others. Spices are certainly the most frequently reported irradiated products $[5,10]$. Although the microbial content of spices varies greatly, in general, black pepper, tur- meric, paprika, chili, and thyme are the most contaminated spices of all [11]. With today's demand for high-quality convenience foods, irradiation as a no thermal treatment which does not affect the fresh state holds promise (in combination with other techniques) for enhancing the safety of many minimally processed, extended shelf-life chilled products [12].

The FDA has evaluated the safety of irradiated food for more than 30 years and has found the process to be safe [13]. The World Health Organization reviewed 500 studies and concluded that food irradiation produces no toxicological, microbiological, or nutritional harm to the consumers [14]. Despite these international reviews, a fruitful topic for critics has been the identification of specific products of irradiation (radiolytic products) [15]. The most frequently detected of these radiolytic products were 2-alkylcyclobutanones [16] because they could be unique to radiation as opposed to any other food preservation process, but more detailed studies were eventually conducted and reviewed and cyclobutanones are not considered a toxicological hazard by food safety authorities [17].

Detection methods for irradiated food, according to the changes they detect, are classified in three main groups: biological, chemical, and physical methods $[6,18,19]$.

One of the biological methods used for evaluation of the irradiation effect is the microbiological testing method. This method has been applied as a standard procedure for microbiological testing of the irradiated vegetables together with the direct epifluorescent filter technique [6].

One simple physical method for detection of irradiated food is optically stimulated luminescence or photostimulated luminescence (PSL). This method gives reliable results for foodstuffs that contain sufficient amount of minerals. Irradiated samples produce a specific signal which is detected and quantified. Registered signal level is compared with two reference threshold values. Most irradiated samples produce signals above the high threshold, and most unirradiated samples produce signals below the low threshold. Intermediate signal levels between the two thresholds suggest that further tests should be made. This method has been used for the detection of irradiation of spices [20], cereals [21], anchovy and shrimps [18]. When minerals are exposed to ionizing radiation, they accumulate energy by which some electrons move to excited energy states. When returning to ground state, some of them remain trapped in the 
crystal lattice. When exposed to light or heat, trapped electrons are released and recombination with holes occurs, resulting in the emission of photons, thus a luminescent signal is obtained [19].

\section{EXPERIMENTAL SECTION}

\subsection{Spice samples}

Red pepper, black pepper and stinging nettle were all a gift from the food processing factory "Vitaminka" from Prilep (North Macedonia). All three spices were gamma irradiated. Red pepper was in the form of powder, while the nettle and black paper were in the form of grains.

\subsection{Irradiation of the samples}

The facility used for irradiation is equipped with cobalt- 60 gamma irradiator. It is located at the Vinča Institute for Nuclear Sciences (Serbia). All the three samples were irradiated with an average dose of $7 \mathrm{kGy}$, with the speed of $9.1 \mathrm{kGy} / \mathrm{h}$, for a duration of 46 min.

\subsection{Determination of the total cell count}

Cell enumeration of the spice samples was performed by standard plate counts and calculated as the number of colony forming units on a gram sample, i.e. the colonies formed from one cell only in order to obtain a pure microbial strain. $25 \mathrm{~g}$ of sample was diluted in $225 \mathrm{ml}$ of water and homogenized (Fig. 1). $1 \mathrm{ml}$ of this solution was inoculated on a Petri dish containing $10 \mathrm{ml}$ Sabouraud $2 \%$ glucose agar (for enumeration of yeasts and molds) or nutritive agar (for enumeration of bacteria), both supplied from Merck, Germany (Fig. 2). All the three spices were incubated on both types of agar. The media were sterilized at $121{ }^{\circ} \mathrm{C}$ for $35 \mathrm{~min}$. The agar plates were incubated at $30{ }^{\circ} \mathrm{C}$ for 5 days. All examined samples were diluted $10^{6}$ times. All analyses were performed in triplicate.

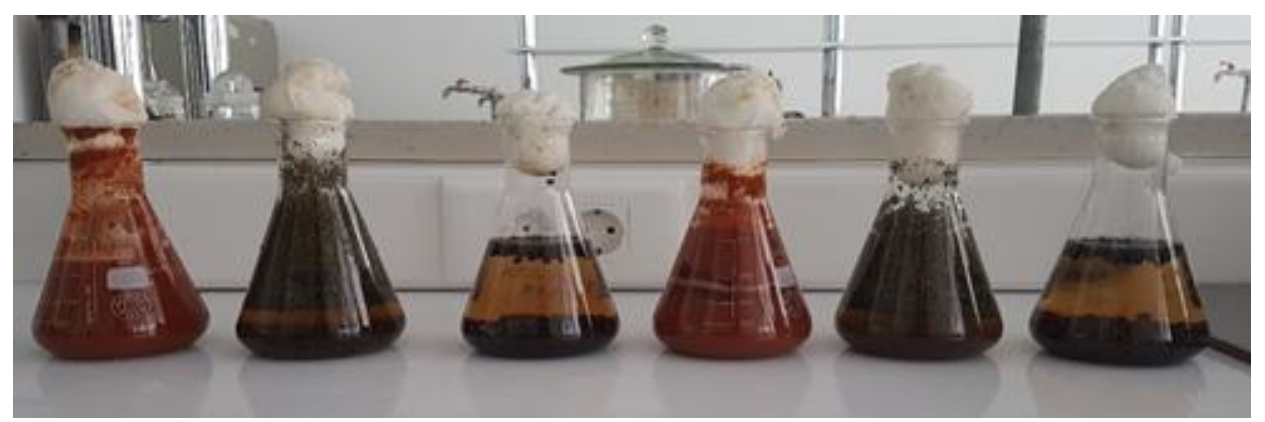

Fig. 1. Extraction of the sample material to be prepared for incubation and enumeration of microbial cells

\subsection{Modified method of agar plate count}

A modified method for enumeration of the total number of microorganisms isolated from the different spices was developed by using micro quantities of samples, but by having final compa- rable dilution coefficients. Thus, the quantities taken for analysis are measured in $5 \mu \mathrm{l}$ quantities. The Petri dish was separated into 4 equal sections, and samples having different dilutions were inoculated on each.
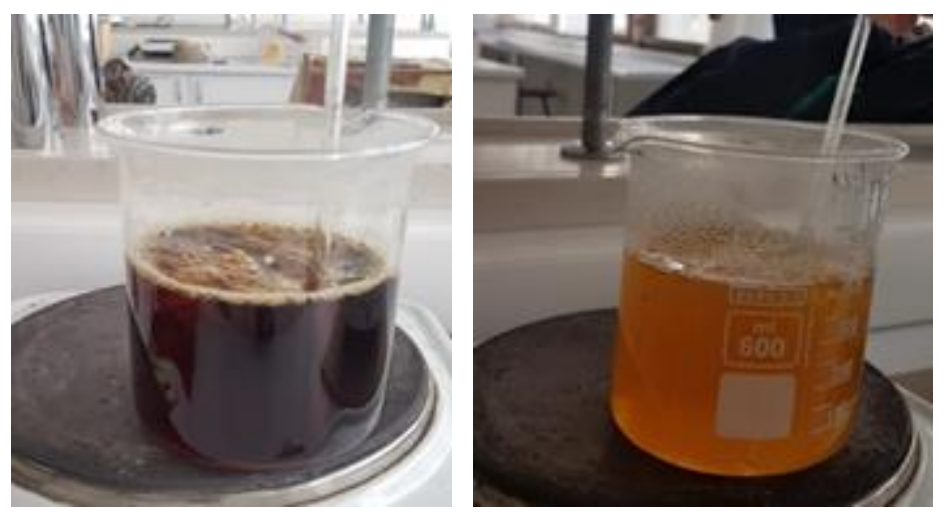

Fig. 2. Preparation of the nutritive agar (left) and Sabouraud $2 \%$ glucose agar (right) 


\subsection{Optically stimulated luminescence and thermoluminescence methods}

The confirmation of the effect of irradiation was performed by using one additional method that is a physical method. Both optically stimulated and thermoluminescence methods were used in order to check if the spices were really irradiated.

Thermoluminescence analysis was done twice for each sample. The first measurement was performed after isolation of silicate minerals. During measurement, the first glow curve is recorded, giving the variation of TL intensity with temperature. The second measurement was done after exposing the sample to a certain dose of ionizing radiation and detecting the signal for the second time, thus obtaining the second glow curve.

TL glow ratio is defined as the ratio of integrated TL intensities of glow 1 to glow 2, evaluated over a stated temperature interval. Identification of samples as irradiated or unirradiated was done according to evaluation of the glow curves by examining the temperature interval of $150{ }^{\circ} \mathrm{C}-250$ ${ }^{\circ} \mathrm{C}$. When minerals are exposed to ionizing radiation, they accumulate energy by which some electrons move to excited energy states. When returning to the ground state, some of them remain trapped in the crystal lattice. When exposed to light or heat, trapped electrons are released and recombination with holes occurs, resulting in the emission of photons, such that a luminescent signal is obtained.

\section{RESULTS AND DISCUSSION}

\subsection{Determination of the total cell count by utilization of conventional agar plate method}

In order to evaluate the effectiveness of the irradiation as a food preservation technique, the microbiological method (agar plate total cell count) was developed for both bacterial and fungi/yeasts total cell count. The appearance of the plates (with nutritive broth agar) incubated by samples from the unirradiated stinging nettle, diluted from $10^{2}$ to $10^{6}$ times, is presented in Figure 3, while the appearance of the plates (having Sabouraud agar broth) incubated by unirradiated red pepper, with the same dilutions from $10^{2}$ to $10^{6}$ times, is presented in Figure 4.

As can be seen from the figures presented, the number of the colony forming units decreases by the increase of the factor of dilution, as was expected in both cases (unirradiated stinging nettle and unirradiated red pepper).

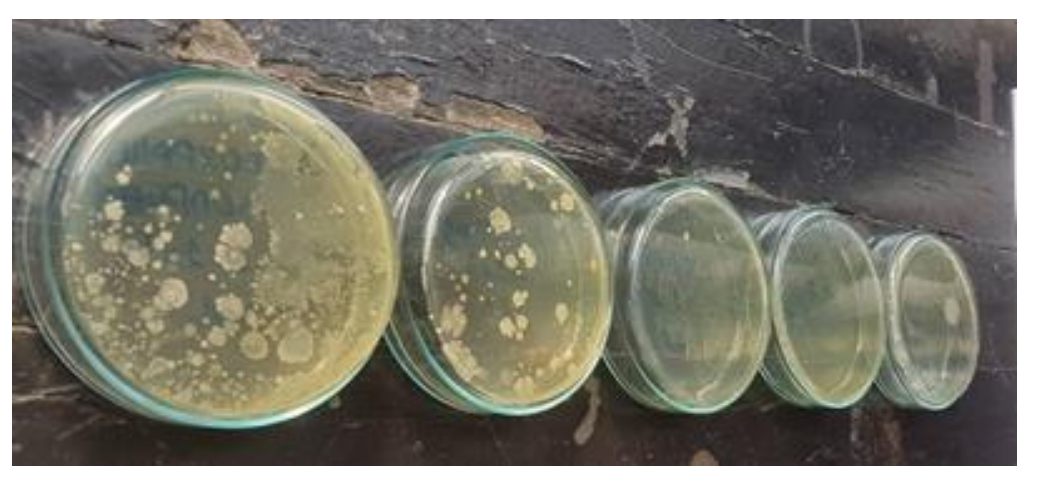

Fig. 3. Agar plate method for microbiological testing: total cell count from the stinging nettle. The dilution factor is increasing towards the right.

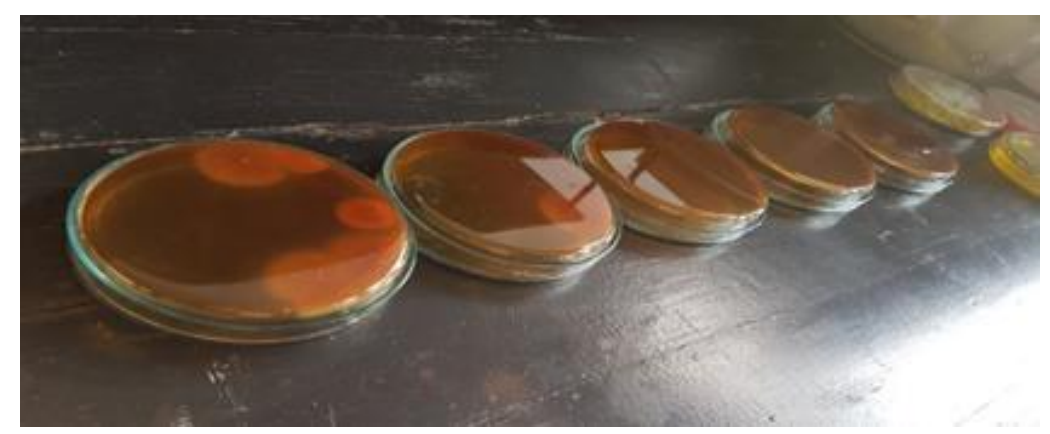

Fig.4. Agar plates with isolated fungi from red pepper samples 
Since the nutritive broth and the Sabouraud glucose broth are selective, it can be suggested that only bacteria were isolated in the first case, and only yeasts and fungi in the second. The results from the colony enumeration of all the three plant samples, both unirradiated and irradiated, on the two different inoculation media used, are presented in Table 1.

From the results presented in the Table 1, one can see that the black pepper did not show any degree of contamination estimated in both irradiated and unirradiated samples. This result can be explained by two possible reasons: 1 . it was irradiated previously or 2. it is very rich with essential oils, and that might be the reason that this spice did not show any microbial contamination since the essential oils are known for their strong antimicrobial activity. It contains the essential oils with strong antimicrobial properties. Interestingly, both the red pepper and the stinging nettle did not show any microbial growth when inoc- ulated on both growth media, after being irradiated. Unlike these cases, unirradiated red pepper showed 2 $\times 10^{6} \pm 1 \times 10^{6}$ and $3 \times 10^{2} \pm 1 \times 10^{2} \mathrm{cfu} / \mathrm{g}$ bacteria and fungi/yeast, respectively. The stinging nettle, on the other hand, did not show any fungal/yeast contamination, while it showed $6.5 \times 10^{4} \pm 1 \times 10^{4} \mathrm{cfu} / \mathrm{g}$ bacterial contamination.

The Erlenmeyer flasks were stored in a refrigerator for two weeks. Samples were obtained from unirradiated red pepper (top) and irradiated pepper (bottom) after two weeks of extraction at $4{ }^{\circ} \mathrm{C}$. The results showed that the unirradiated red pepper became subjected to much greater contamination, while the irradiated red pepper wasn't contaminated even after two weeks of storage. Figure 5 shows the bacterial growth of the samples incubated on nutritive agar plates, while Figure 6 shows fungal growth of the samples incubated on Sabouraud agar plates.

\section{Table 1}

Cell enumeration in the samples of stinging nettle, red pepper, and black pepper

\begin{tabular}{lcc}
\hline \hline Type of sample & $\begin{array}{c}\text { Total cell count of bacteria } \\
(\mathrm{cfu} / \mathrm{g})\end{array}$ & $\begin{array}{c}\text { Total cell count of fungi and yeasts } \\
(\mathrm{cfu} / \mathrm{g})\end{array}$ \\
\hline Red pepper unirradiated & $2 \times 10^{6} \pm 1 \times 10^{6}$ & $3 \times 10^{2} \pm 1 \times 10^{2}$ \\
Red pepper irradiated & $/$ & $/$ \\
Black pepper unirradiated & $/$ & $/$ \\
Black pepper irradiated & $/$ & $/$ \\
Stinging nettle unirradiated & $6.5 \times 10^{4} \pm 1 \times 10^{4}$ & $/$ \\
Stinging nettle irradiated & $/$ & $/$ \\
\hline \hline
\end{tabular}

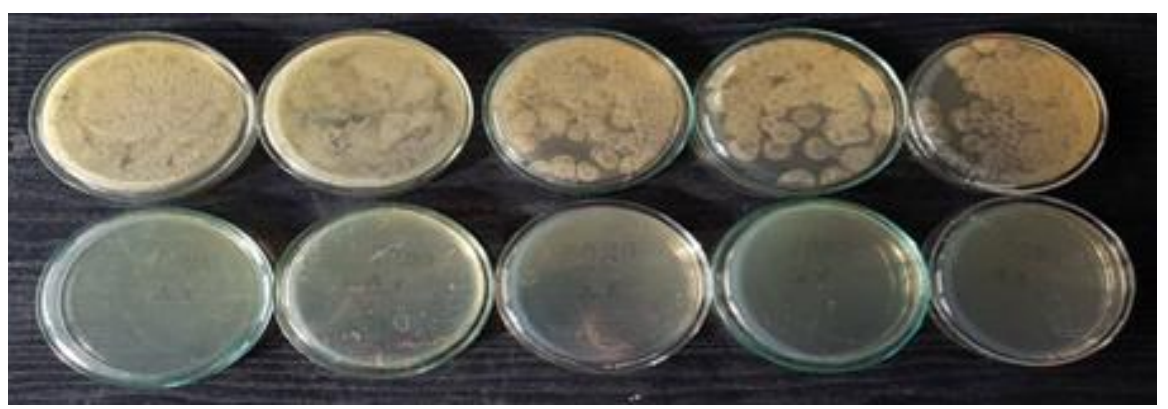

Fig. 5. Bacterial growth of the samples incubated on a nutritive agar plates. Unirradiated red pepper (top) and irradiated pepper (bottom) after two weeks extraction at the temperature of $4^{\circ} \mathrm{C}$.

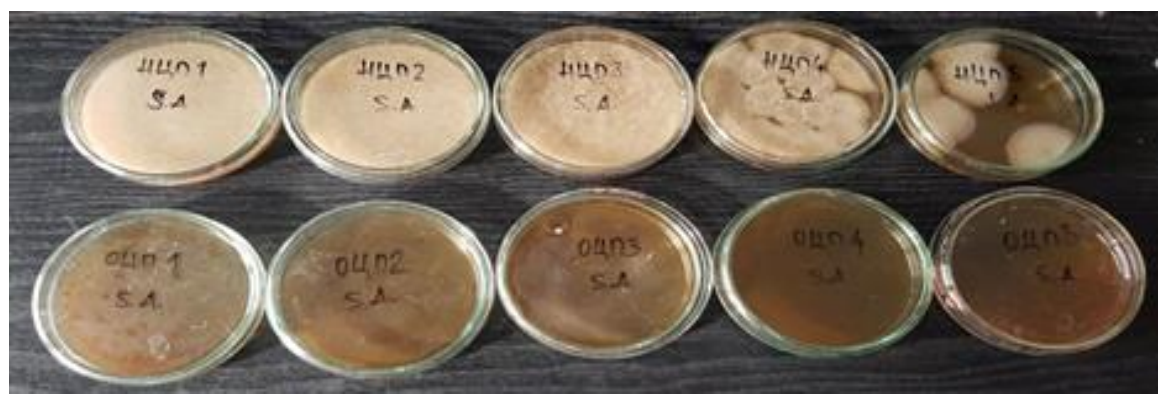

Fig. 6. Fungal growth of the samples incubated on a Sabouraud agar plates. Unirradiated red pepper (top) and irradiated pepper (bottom) after two weeks extraction at the temperature of $4{ }^{\circ} \mathrm{C}$. 


\subsection{The modified microbiological method}

The utilization of the modified microbiological method resulted in establishing a much shortened procedure for microbiological testing of the total cell count of the spices (Figure 7), but with less punctuality, and less bacterial strains were isolated. However, this method is not as precise as the first one. Due to the use of the smaller sample amounts, it certainly resulted in larger errors while determining the total number of microorganisms.

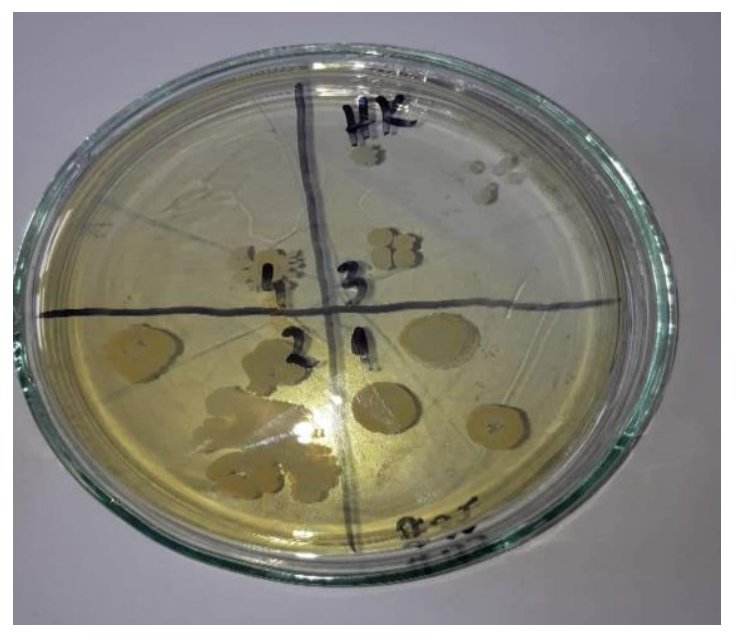

Fig. 7. The segmentation of the plate on four different parts having 4 different dilution factors

\subsection{The preliminary identification of the isolated microorganisms}

The microorganisms grown on agar plates from the spice samples examined were preliminary identified. The agar plate containing nutritive broth with grown bacterial consortia isolated from stinging nettle is shown in the Figure 8 (left), while the fungi grown from the sample of red pepper are shown in the Figure 9 (left). It is obvious that different species of bacteria isolated from the stinging nettle can be identified, while at least two different fungi isolated from the red pepper can be discriminated. The microscopic appearance of the one bacterial strain isolated from the stinging nettle is presented in the Figure 8 (right), and one fungal strain isolated from red pepper is presented in the Figure 9 (right). As can be seen, bacteria from the Bacillus strain can be recognized from stinging nettle (Fig. 8, right), while the conidial structure can be recognized in the Figure 9 right (microscopic view of the red pepper, probably Aspergillus). Thus, the three microbial strains preliminarily assumed to be present in the samples are: Bacillus subtilis (stinging nettle), Aspergillus niger and Aspergillus flavus (red pepper).

Spices are used in very small quantities, but can easily be contaminated by mesophylic, sporogenic, and asporogenic bacteria. Microorganisms of public health significance such as Salmonella, Escherichia coli, Clostridium perfringens, Bacillus cereus, and toxigenic moulds can also be present [5]. Many commercial food processors fumigate spices with methyl bromide to eliminate insects or with ethylene oxide to eliminate bacteria and moulds. However, it has been found that both methyl bromide and ethylene oxide are extremely toxic compounds. The thermal processing, such as pasteurization and sterilization, are also inadequate since they cause the loss of thermolabile aromatic volatiles and/or additional thermally induced changes (e.g., thermal decomposition or production of thermally induced radicals). Thus, the gamma irradiation is a suitable cold sterilization process for these kinds of food additives.
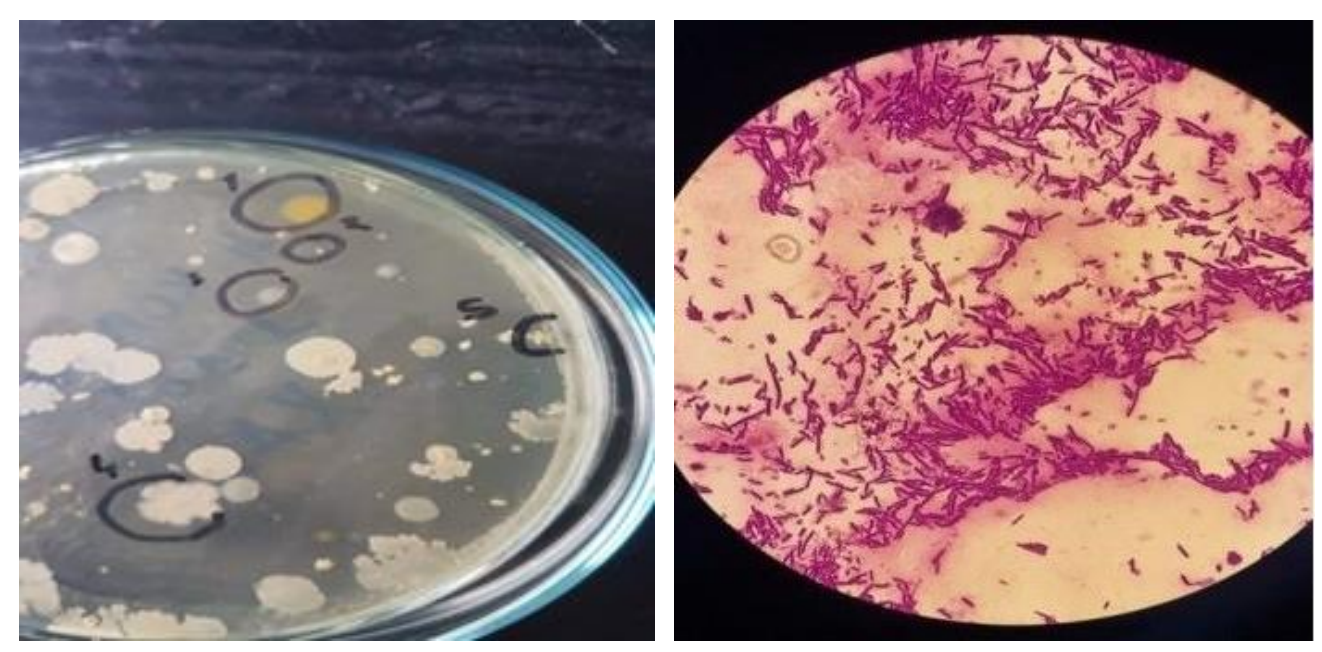

Fig. 8. The bacteria consortium grown from the sample of unirradiated stinging nettle (left) and microscopic view of Bacillus bacterial strain (right) 

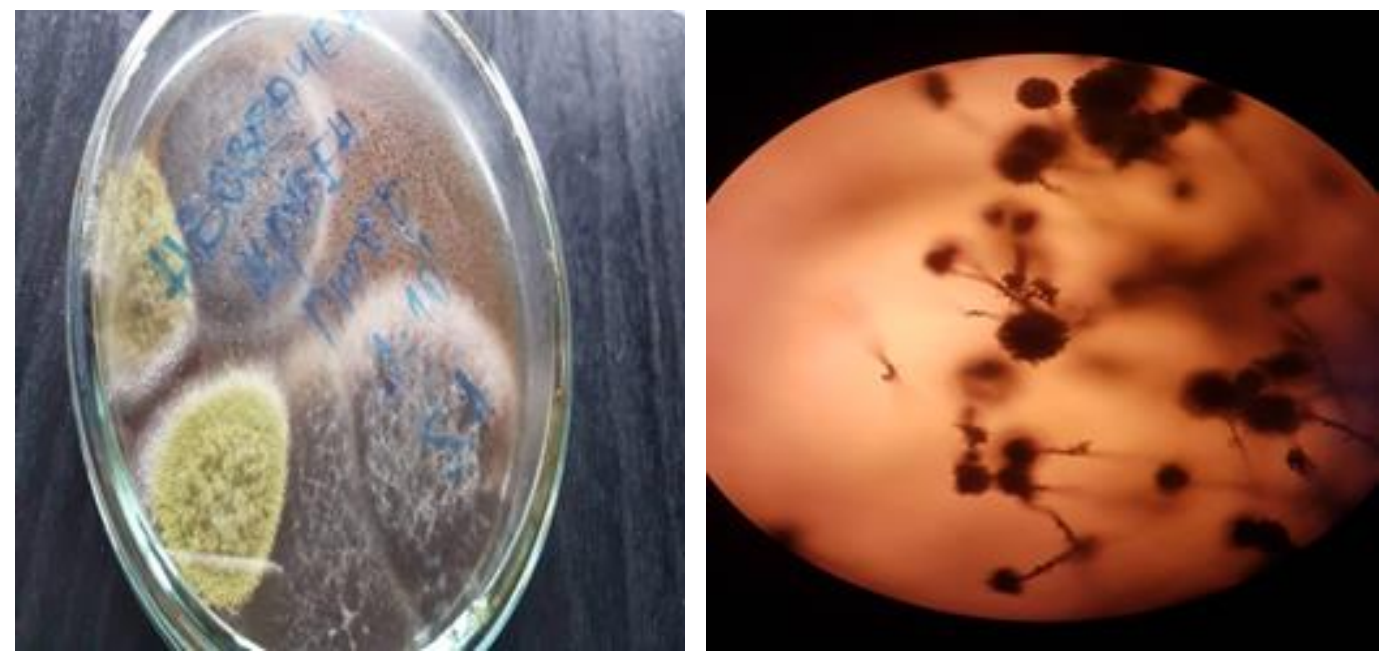

Fig. 9. Fungi grown from a sample of unirradiated red pepper (left) and microscopic view of fungal conidia from Aspergillus niger (right)

Samples were tested by the photostimulated luminescence method, giving luminescence signals above the high threshold. In order to confirm the photostimulated luminescence results, samples were also tested by the thermoluminescence method. This gives very punctual results and can confirm if the samples tested were really irradiated or not. Unfortunately, not enough minerals from the black pepper could be detected, thus the results obtained only refer to the red pepper and the stinging nettle. The first glow curves exhibit a maximum in the temperature interval of $150{ }^{\circ} \mathrm{C}-250{ }^{\circ} \mathrm{C}$, which is an indication of the irradiation treatment. By comparing the two glow curves, the obtained glow ratio values are greater than 0.1 , which confirms that the samples have been irradiated. Figure 10 shows the glow ratio for red pepper, while Figure 11 shows the glow ratio for the stinging nettle.
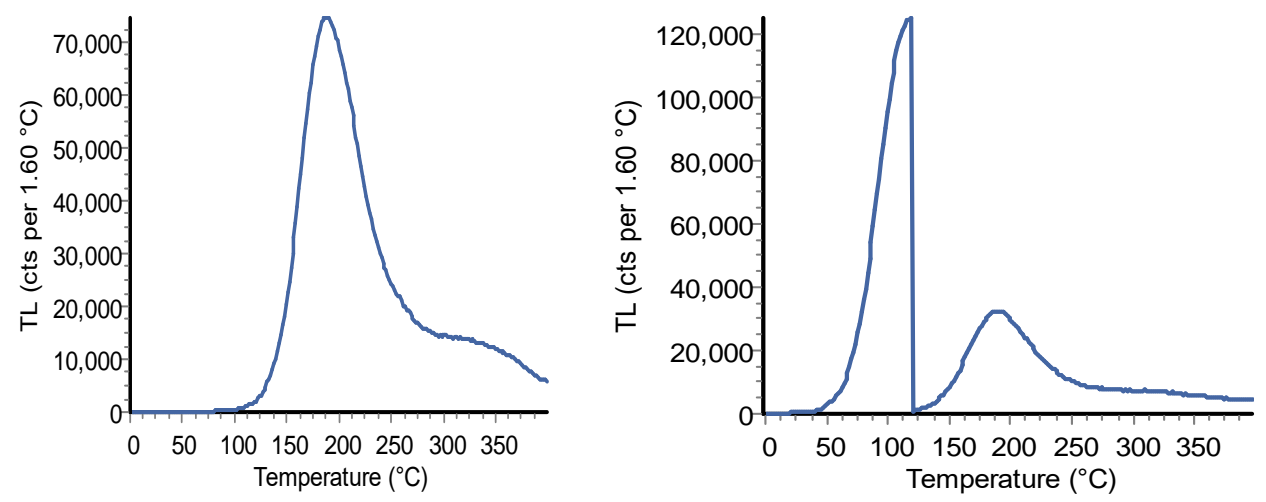

Fig.10. Glow ratio for red pepper
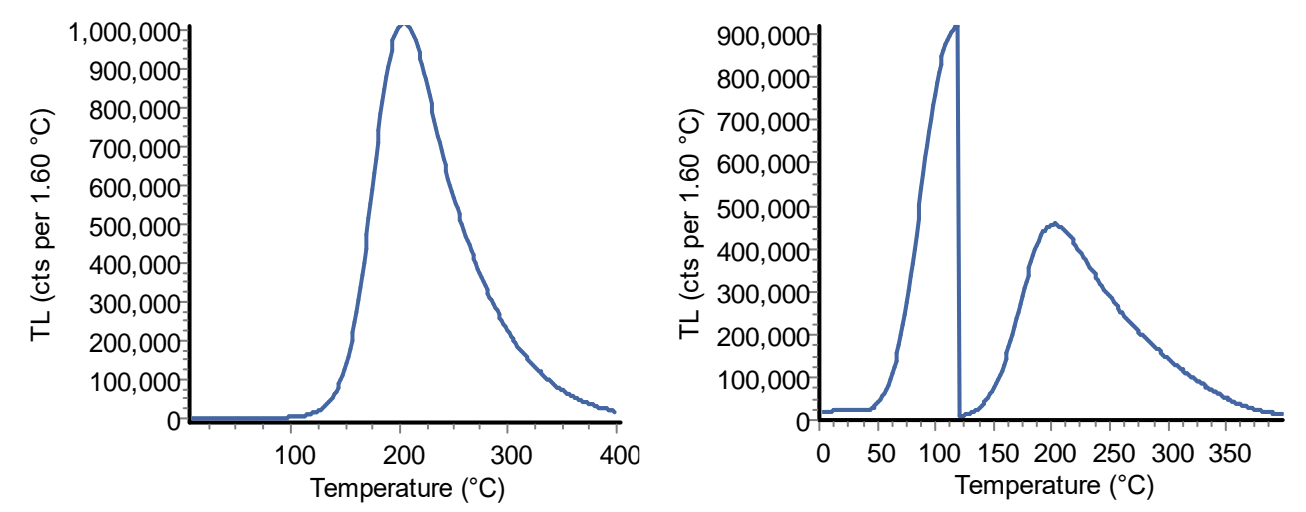

Fig. 11. Glow ratio for stinging nettle 
In summary, the glow ratio is 2.38 for the red pepper, while the glow ratio for stinging nettle is 2.14 . The terminal count is $94514 \pm 310$ (POSITIVE) for the red pepper, while the terminal count is $65894 \pm 260$ (POSITIVE) for the stinging nettle.

\section{CONCLUSIONS}

The above results show that the gamma irradiation method for cold sterilization of spices is very successful. The microbiological testing method would be an easy to use technique as a biological method for detection and for indicating the microbial quality of spices. The microbiological method can be used in a combination with physical methods in order to confirm if the material was previously treated with ionizing radiation or not. The methods like optically stimulated and thermoluminescence have been used and appear to be very accurate. This is a first step in establishing an accurate method for detecting whether the food that we import has been previously ionized or not and is a first step in development of a laboratory for analysis of the irradiated food in the Republic of North Macedonia.

\section{REFERENCES}

[1] E. Zanardi, A. Caligiani and E. Novelli, New insights to detect irradiated food: an overview, Food Analytical Methods, 1, 224-235 (2017).

DOI: https://doi.org/10.1007/s12161-017-0992-1

[2] Å. Stenmarck, C. Jensen, T. Quested and G. Moates, Estimates of European food waste levels, (2016). Retrieved from: http://www.eufusions.org/phocadownload/Publications/Estimates\%20of\%20European\%20food\%20waste $\% 2$ Olevels.pdf

[3] P. Loaharanu, Irradiation as a cold pasteurization process of food, Veterinary Parasitology, 64, 71-82 (1996). DOI: https://doi.org/10.1016/0304-4017(96)00964-8

[4] N. K. Kortei, G. T. Odamtten, M. Obodai, V. Appiah, P. T. Akonor, Determination of color parameters of gamma irradiated fresh and dried mushrooms during storage, Croatian Journal of Food Technology, Biotechnology and Nutrition, 10, 66-71 (2015).

[5] J. Sádecká, Irradiation of spices - a review, Czech Journal of Food Sciences, 25, 231-242 (2007).

DOI: https://doi.org/10.17221/684-CJFS

[6] M. Araújo, R. Duarte, P. Silva, E. Marchioni and A. Villavicencio, Application of the microbiological method DEFT/APC to detect minimally processed vegetables treated with gamma radiation, Radiation Physics and Chemistry, 78, 691-693 (2009).

DOI: https://doi.org/10.1016/j.radphyschem.2009.04.015

[7] M. Iqtedar, B. Sarfraz, R. Abdullah, A. Kaleem \& S. Naz, Effect of $\gamma$-irradiation doses on the sensory and microbial quality of dates (Phoenix dactylifera), Biologia, 61, 227-233 (2015).

DOI: https://doi.org/10.1016/B978-0-12-818649-7.00022-9
[8] I. U. Mohammadzai, Z. Shah, I. Ihsanullah, H. Khan, H. Rashid, Effect of gamma irradiation, packaging and storage on the nutrients and shelf life of palm dates, Journal of Food Processing and Preservation, 34, 622-638 (2010). DOI: https://doi.org/10.1111/j.1745-4549.2009.00421.x

[9] L. A. Antonio, A. Fernandes and A. Bento, Gamma irradiation preservation of chestnut fruits: effects on color and texture, European Scientific Journal, 3, 239-245 (2013). DOI: https://doi.org/10.19044/esj.2013.v9n10p\%p

[10] M. Polovka, M. Suhaj, Classification and prediction of $\gamma$-irradiation of ten commercial herbs and spices by multivariate evaluation of properties of their extracts, Journal of Food and Nutrition Research. 52, 45-60 (2013).

[11] R. A. Molins, Food Irradiation: Principles and Applications. Wiley, New York, 2001.

[12] J. Farkas, Irradiation as a method for decontaminating food. A review, International Journal of Food Microbiology, 44, 189-204 (1998).

DOI: https://doi.org/10.1016/S0168-1605(98)00132-9

[13] FDA. Food Irradiation: What You Need to Know, 2018, https://www.fda.gov/food/buy-store-serve-safefood/food-irradiation-what-you-need-know

[14] D. Acheson, J. H. Steele, Food irradiation: A public health challenge for the 21 st century, Clinical Infectious Diseases, 33, 376-377 (2001). DOI: https://doi.org/10.1086/321899

[15] P. B. Roberts, Food irradiation is safe: Half a century of studies, Radiation Physics and Chemistry, 105, 78-82 (2014). DOI: 10.1016/j.radphyschem.2014.05.016

[16] E. Marchioni, S. Ennahar, P. Horvatovich, B. Ndiaye, Production yields of 2-alkylcyclobutanones in irradiated foods, International Nuclear Atlantic Conference - IN$A C$, (2009).

[17] U.S. Food and Drug Administration. Irradiation in the Production, Processing and Handling of Food, 2014, https://www.federalregister.gov/documents/2014/02/25/ 2014-03976/irradiation-in-the-production-processingand-handling-of-food

[18] H. Chung, H. Delincée and J. Kwon, The application of different detection methods for irradiated dried anchovy and shrimp, Radiation Physics and Chemistry, 63, 411414 (2002). DOI: https://doi.org/10.1016/S0969-806X(01)00589-8

[19] M. Ginovska, H. Spasevska, L. Stojanovska-Georgievska, I. Sandeva, M. Kochubovski, Procedure for detection and control of irradiated food. Journal of Environmental Protection and Ecology, 17, 402-412 (2016).

[20] G. Aygun, F. Bozoglu, and E. Bulur, Detection of gamma irradiated spices with OSL method and its reliability, Natural Science and Discovery, 2, 9 (2016). DOI:https://doi.org/10.20863/nsd.44208

[21] M. Cutrubinis, H. Delincée, M. Stahl, O. Röder and H. Schaller, Detection methods for cereal grains treated with low and high energy electrons, Radiation Physics and Chemistry,72, 639-644 (2005).

DOI:https://doi.org/10.1016/j.radphyschem.2004.03.089 